\title{
An Improved Procedure of the Metagenomic DNA Extraction from Saline Soil, Sediment and Salt
}

\author{
Fereshteh Jookar Kashi \\ Biotechnology Division, Department of Molecular and Cell Biology, Faculty of Chemistry, \\ University of Kashan, Kashan, Iran \\ Jookar@kashanu.ac.ir
}

Keywords: DNA extraction, Metagenome, DNA, Saline Sample, Molecular Methods

\begin{abstract}
A new modified protocol has been developed for extracting pure community inhibitorsfree DNA from saline soils, sediments and salts. Amplification of DNA from soil and sediment is often inhibited by copurified contaminants. A rapid, inexpensive, large-scale DNA extraction method involving minimal purification has been developed that is applicable to saline samples. Using a widely used a newly modified direct DNA extraction method proposed in this report, DNA was extracted from samples of Urmia Lake in diverse geological location in Iran and quantity of the DNA were examined. We developed an improved method to extract DNA include the combination of physical, chemical and mechanical lysis methods from saline samples. In the earlier reports, skim milk as an adsorption competitor was added to buffer DNA extract. In current study, we added skim milk to buffer DNA extraction. The results showed that skim milk was useful as an additive for extract DNA from saline samples. This method is applicable to molecular community analysis of saline samples which strongly adsorb DNA. The methods appear to have wide applicability in investigating molecular diversity and exploring functional genes from the total DNA. The extracted DNA was used to successfully amplify 16SrRNA region and functional genes. The amplicons were suitable for further applications such as diversity based analysis by denaturing gradient gel electrophoresis (DGGE) and cloning library.
\end{abstract}

\section{Introduction}

Microorganisms are indicated in all habitats, including soil, sediment, marine and terrestrial subsurface, animals and plant tissues. They have a key role in the biogeochemical cycles of the biosphere and represent an enormous reservoir of novel valuable molecules for health or industry [1].

In the last decade, microbial ecologists have employed DNA extraction methods from soils and sediments to describe and quantify the diversity of complex environmental microbial communities, therefore, the genomes of uncultured indigenous microorganisms are available for molecular analysis [2].

Sand, silt, clay and organic matter content through the organization of micro- and macroaggregates are defined as Soil tissue and structure [3, 4].

The direct extraction of DNA from soil and sediment are essential for the study of microbial communities including unculturable microorganisms [5]. There is an increasing interest in the extraction of DNA from soil, since molecular techniques help the analysis of the microbial community including unculturable microorganisms. Though various methods of direct DNA extraction have been devised, it remains difficult to extract DNA from some soils [6]. Microorganisms through different mechanisms to bind soil particles of clay that reduce access to the bacteria [1].

Inhibitors of soil and sediment environment are including bilirubin, bile salts, urobilinogens and polysaccharides. Of these inhibitors, humic substances have been detected to be the most recalcitrant [7].

Most of the methods used to extract DNA from soils and sediments are based on in situ lysis of cells. This is typically performed by physical methods (e.g. bead mill homogenization, sonication 
and/or freeze-thawing), chemical procedures (e.g. utilizing detergents such as SDS or Sarkosyl) or a combination of both. In situ lysis is the most efficient method for microbial diversity in the sedimentary matrix. These procedures allow higher DNA yields than other methods based on cell lysis for DNA recovery. DNA yield from marine sediments is an important factor in the evaluation of microbial diversity, but other factors such as the coextraction of substances must also be considered, which can interfere with the analysis [2].

Some studies reported that competitors such as skim milk were effective in clay-rich soils.

Each extraction protocol should maximize nucleic acid isolation and copurification of enzymatic inhibitors reduces. DNA extraction from soils containing clay is difficult, given the tight binding of DNA strands to clay soil particles. Additionally, extracellular DNA binds to clay and is copurified with soil humic substances. Inhibitors prevented from the activity of enzymes such as restriction endonucleases and DNA polymerase. Although clay-bound DNA can be PCR amplified in the absence of inhibitors. It is very important to obtain nucleic acids from different environmental samples because DNA techniques allow less biased access to a greater portion of uncultivable microorganisms. This technique is also a useful tool for studying the structure and diversity of microbial communities [8].

Separation and purification of high molecular weight DNA is important because further steps of metagenomics rely upon it. However, DNA extracts from humus-rich soils is difficult because humic substances can co-precipitate with DNA and interfere with its downstream processing.

The presence of trace amounts of humic compounds can significantly affect downstream steps of PCR amplification, restriction digestion and transformation by binding with the enzymes and chelate $\mathrm{Mg}^{2+}$ Ions [9].

DNA extracts from entire subsurface communities is important. There is challenge due to the low concentrations of nucleic acids that can be absorbed to sediment/rock particles, and the frequent co-extraction of enzymatic inhibitors including, heavy metals, colloids, fulvic and humic acids, etc. Therefore, DNA extraction method alone cannot be used to estimate microbial diversity, but this procedure must be combined with other methods $[10,11]$.

Molecular techniques for the study of soil microbial communities often depend on the extraction of DNA directly from soils. These extractions are complicated by humic substances that are inhibitory to PCR and restriction enzymes or being too highly colored for blot hybridization protocols. Many different published protocols exist, but none was suitable enough to be generally accepted as a standard [12].

The aim of this study was to develop a cost-effective method for extracting DNA directly from saline samples. Therefore, Soil, salt and sediment were collected from Urmia Lake in Iran. In current study, we used a method, by combining physical, chemical and mechanical lysis methods. Skim milk added to buffer extract as adsorption competitor described by Yuko Hoshino and Naoyuki [5]. The combine of our method and skim milk was most effective in extracting DNA from saline soil. This protocol is effective for the analysis of microbial communities by PCR-DGGE and cloning analysis.

\section{Material and Methods}

\section{Collection and analysis of samples}

Saline soil, sediment and salt samples were collected from Urmia Lake $\left(37^{\circ} 32^{\prime} \mathrm{N}, 045^{\circ} 43^{\prime}\right.$ E) in the northwest of Iran. Samples consisted of a mixture of 20 sub-samples taken from different area of approximately $30 \mathrm{~cm}^{2}$ just below the soil surface. Samples were scooped into sterile polythene bag and transported under refrigeration to laboratory, where it was immediately analyzed.

Each sample from different sites at each location was combined and used for further experimentation. Before DNA extraction procedures, the samples were sieved (2-mm mesh) and small parts of plants, rocks, insects and roots were removed. In the laboratory, the core liners were aseptically opened and subsamples were collected from the inner part of the cores using end-cut sterile $2 \mathrm{ml}$ syringes. Samples were frozen at $-80^{\circ} \mathrm{C}$ for metagenomic DNA isolation. 
The temperature and $\mathrm{pH}$ were measured at each sampling point using portable instruments. Samples (200g from each site) were mixed then saturated pastes were prepared from each sample according to standard methods [13]. Subsequently, by suction-filtration of the paste, a sample of the saturation-paste extract was obtained. Saturation-paste extract were applied for determining total salt concentration by titration according to the method of Mohr [14]. By extracting the liquid phase of the saturation paste under partial vacuum estimates of solution concentrations of $\mathrm{Na}^{+}, \mathrm{K}^{+}, \mathrm{Ca}^{2+}$, $\mathrm{Mg}^{2+}, \mathrm{Cl}^{-}, \mathrm{HBO}_{3}, \mathrm{NO}_{3}{ }^{-}, \mathrm{SO}_{4}{ }^{2-}, \mathrm{Mn}^{2+}, \mathrm{SeO}_{4}{ }^{2-}, \mathrm{HCO}_{3}{ }^{-}, \mathrm{CO}_{3}{ }^{2-}$ can be determined. The contents of various ions were measured $\mathrm{Cl}^{-}$by titration with $\mathrm{AgNO}_{3}$ and $\mathrm{Mg}^{2+}$ by atomic absorption spectrophotometer, $\mathrm{Na}^{+}$by flame spectrophotometry and $\mathrm{Ca}^{2+}$ by complexometry method using EDTA [15] are summarized in Table 1.

\section{Extraction of metagenomic DNA}

A newly modified direct saline samples DNA extraction method is presented. The several steps in DNA extraction process were as follows: the first step is preparation and removal of salt from samples. Ten gram of each sample was first washed three times with $50 \mathrm{ml}$ PBS buffer. These samples washing aimed at the removal of debris and salt. Saline samples were introduced into a $250 \mathrm{ml}$ Erlenmeyer flask containing $100 \mathrm{ml}$ PBS buffer with $0.1 \mathrm{~g}$ for soil and salt and $0.4 \mathrm{~g}$ for sediment (tween 80, pH 7). The mixture was incubated under constant agitation overnight at room temperature. The supernatant from this suspension was centrifuged at $5000 \mathrm{rpm}$ for $10 \mathrm{~min}$. The pellet was washed with PBS buffer at $3000 \mathrm{rpm}$ for $3 \mathrm{~min}$. These steps were not performed for salt sample.

The pellets were resuspended in $5 \mathrm{ml}$ of $1 \%$ Sodium dodecyl sulfate (SDS) and an equal amount of sterile glass beads $(0.1 \mathrm{~mm}$ diameter $)$ were added to each pellets and vortexed to mix thoroughly for 5 min after the bead-beating method was supplemented with $0.5 \mathrm{ml}$ of lysozyme $\left(10 \mathrm{mg} / \mathrm{ml} \mathrm{TE}\right.$ buffer) at $37^{\circ} \mathrm{C}$ for $1 \mathrm{~h}$.

After incubation, $10 \mathrm{ml}$ of lysis buffer (4\% SDS, $50 \mathrm{mM}$ Tris-HCL, $100 \mathrm{mM}$ EDTA, 1\% cetyltrimethyl-ammonium bromide (CTAB), $\mathrm{pH}$ 8.0) with $40 \mathrm{mg}$ skim milk for saline soil and salt and $100 \mathrm{mg}$ skim milk for sediment were added to the mixture and incubated at $56{ }^{\circ} \mathrm{C}$ for $1 \mathrm{~h}$.

After breaking the microbial cells in soil, the extracted DNA was purified. The upper aqueous phase was extracted with equal volume of phenol and supernatant were collected by low speed centrifugation (10000 g) for $2 \mathrm{~min}$. The aqueous layer was transferred to a new tube and an equal volume of chloroform was added.

The tubes containing the above solution were subjected to gentle rolling (to prevent shearing of DNA) until the two distinct layers disappeared and a homogenous suspension formed.

These tubes were centrifuged at $10000 \mathrm{~g}$ for $2 \mathrm{~min}$. Two distinct layers were obtained an upper aqueous transparent layer containing nucleic acids and the lower organic layer containing pigments and cell debris and the upper aqueous layer was transferred to a fresh $50 \mathrm{ml}$ tubes carefully, to avoid any contamination from the lower layer. This step is repeated three times.

Three volumes of ethanol and 0.1 volume of $2 \mathrm{M}$ sodium acetate were then added and the mixure was kept at $-20^{\circ} \mathrm{C}$ overnight and the DNA molecule is precipitated out. The samples were centrifuged and the pellets were resuspended in $70 \%$ ethanol. The pellets were washed three times with ice-cold $70 \%$ ethanol and once with $95 \%$ ethanol and air dried for $20 \mathrm{~min}$. The dried pellet was finally dissolved in $100 \mu \mathrm{TE}$ buffer (10 mM Tris [pH 8.0],1 mM EDTA). As well as, this protocol is applied for the samples without the presence skim milk. For visualizing the DNA extracts, $5 \mu 1$ of each extract was electrophoresed on 1\% agarose gels in $1 \mathrm{X}$ TBE buffer, which were then stained with ethidium bromide and examined under UV light. The same samples were also performed DNA extraction using Fast DNA ${ }^{\mathrm{TM}}$ SPIN Kit for Soil (Qbiogene, Carlsbad, CA, USA). DNA extraction was performed from samples using this kit according to the manufacturers recommendations.

\section{PCR amplification of metagenomic DNA}

To further estimate the efficiency of the DNA extraction methods, the extracted DNA from samples were used as templates for PCR amplification. Prokaryotic diversity was investigated using gene fragments encoding 16Sr DNA and bacteriorhodopsin (bop gene) as molecular markers. PCR 
products were then cloned using the Fermentas TA cloning according to the manufacturer's directions and clone libraries were constructed for gene targeted. Metagenomics was amplified by PCR using different primers were listed in Table 1.

The reaction mixture contained $0.5 \mu \mathrm{l}(10 \mathrm{mM})$ of each deoxynucleoside triphosphate, $1 \mathrm{U}$ of Taq DNA polymerase, $5 \mu \mathrm{l}$ buffer $(5 \mathrm{X}), 5 \mu 1 \mathrm{MgCl}_{2}(20 \mathrm{mM}), 1 \mu \mathrm{l}(10 \mathrm{pM})$ of each primer and about $20 \mathrm{ng}$ of genomic DNA template in a total volume of $50 \mu \mathrm{l}$. PCR products were checked on a $1 \%$ agarose gel stained with ethidium bromide under UV excitation. The PCR conditions were as follows; $95^{\circ} \mathrm{C}$ for $5 \mathrm{~min}$, followed by 30 cycles of $94^{\circ} \mathrm{C}$ for $60 \mathrm{~s}, 50^{\circ} \mathrm{C}$ for $60 \mathrm{~s}$ and $72^{\circ} \mathrm{C}$ for $60 \mathrm{~s}$, and a final extension at $72^{\circ} \mathrm{C}$ for $7 \mathrm{~min}$. The PCR products were purified with the GenEluteTM PCR Clean-Up Kit (sigma aldrich).

Table 1. List of PCR primers.

\begin{tabular}{|c|c|c|c|}
\hline $\begin{array}{c}\text { Name } \\
\text { Primer }\end{array}$ & Sequence & Fragment amplified & References \\
\hline 27F & 5'-AGAGTTTGATCMTGGCTCAG-3' & 16SrDNA (Bacteria) & {$[17]$} \\
\hline 1492R & 5'-GGTTACCTTGTTACGACTT-3' & 16SrDNA (Bacteria) & {$[16]$} \\
\hline $341 \mathrm{~F}$ & 5'-GCclamp -CCTACGGGAGGCAGCAG-3' & 16SrDNA (Bacteria) & {$[18]$} \\
\hline $344 \mathrm{~F}$ & 5'-GCclamp-ACGGGGCGCAGCAGGCGCGA-3' & 16SrDNA (Archea) & {$[18]$} \\
\hline $907 \mathrm{R}$ & 5'-CCGTCAATTCCTTTRAGTTT-3' & $\begin{array}{c}\text { 16SrDNA (Bacteria and } \\
\text { Archea) }\end{array}$ & {$[18]$} \\
\hline bop1 & 5'-GAC TGG YTG TTC ACS ACR CC-3' & bop gene (Archea) & {$[19]$} \\
\hline bop2 & 5'-ASG TCR AKS ACC ATG AA-3' & bop gene (Archea) & {$[19]$} \\
\hline
\end{tabular}

\section{Results}

The results demonstrated that samples had a $\mathrm{pH}$ range between 7.2-7.5. The temperature of the sampling sites was between $20-25{ }^{\circ} \mathrm{C}$, the salinity of the samples ranged from $14-96 / 8 \%$ total salts. The chemical analysis of the samples is summarized in Table 2.

Table 2. Chemical and physical characteristics of samples Urmia Lake.

\begin{tabular}{|c|c|c|c|c|c|c|c|c|c|c|}
\hline $\begin{array}{c}\text { Sample } \\
\text { Type }\end{array}$ & $\begin{array}{c}\text { Sali- } \\
\text { nity\% }\end{array}$ & $\mathbf{p H}$ & \multicolumn{9}{|c|}{$\begin{array}{c}\text { Ion concentration } \\
(\mathbf{m g} / \mathbf{k g})\end{array}$} \\
\cline { 4 - 11 } & & & $\mathrm{Fe}^{2+}$ & $\mathrm{Na}^{+}$ & $\mathrm{Cl}^{-}$ & $\mathrm{K}^{+}$ & $\mathrm{Mg}^{2+}$ & $\mathrm{Ca}^{2+}$ & $\mathrm{HCO}^{3-}$ & $\mathrm{SO}_{4}{ }^{2-}$ \\
\hline Soil & 14.0 & 6.77 & 14.8 & 60500 & 1863750 & 1500 & 950 & 1200 & 976000 & 4080 \\
\hline Sediment & 32.39 & 7.31 & 0.6 & 100000 & 3337000 & 8000 & 14000 & 550 & 366000 & 240000 \\
\hline Salt & 96.8 & 7.37 & 0.037 & 540000 & 11981250 & 1500 & 81000 & 25750 & 72200 & 16500 \\
\hline
\end{tabular}

In contrast, DNA sample extracted with skim milk- based method had high yield, and no DNA could be extracted from the same samples without skim milk (Figure 1).

In this study, $40 \mathrm{mg}$ of skim milk were added to samples include soil, sediment and salt on bead-beating. DNA is extracted in the presence of skim milk from soil and salt samples but sediment sample with the same amount of skim milk had no DNA extraction. The next time, the procedure was repeated with $100 \mathrm{mg}$ of skim milk for sediment and DNA extraction was successful.

In addition, the sizes of metagenomic DNA fragments obtained by this method were larger than $10 \mathrm{~kb}$ and no obvious DNA degradation and low molecular weight contaminants were visible.

A commercial soil DNA isolation kit was also used to extract DNA from the same samples to compare the efficiency of different methods. These results indicated that the kit method was not detected DNA.

This protocol is simple, short and facilitates rapid isolation of PCR amplifiable total genomic DNA from saline samples. The method yielded good quality of the DNA suitable for metagenomic studies. The results are also significant for extreme environments, particularly saline habitats, are explored for their metagenomic potential. The successful PCR amplification of metagenomic DNA using primers gave the amplification of $\sim 450-1500 \mathrm{bp}$ (Figure 2,3) band which cloned indicated that the DNA samples were free of any PCR inhibitors. From the randomly selected colonies, colony PCR was carried out (Figure 4) and the positive clones were sequenced. 


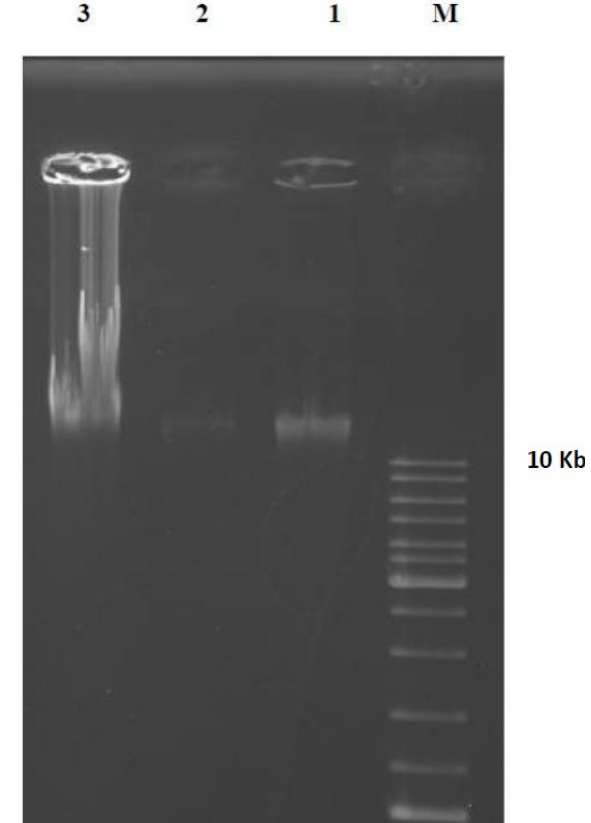

Figure 1. Gel electrophoresis (\%1 agarose) of DNA extracted from samples. DNA extracted from soil, salt, sediment are shown in lines 1, 2 and 3 respectively.

\section{M bop}

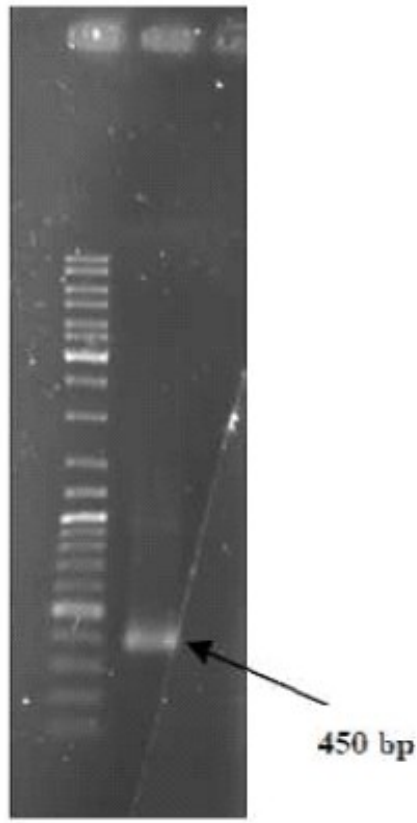

Figure 3. DNA fragments obtained by PCR amplification of bop genes using templates. Lane $\mathrm{M}$ : marker.

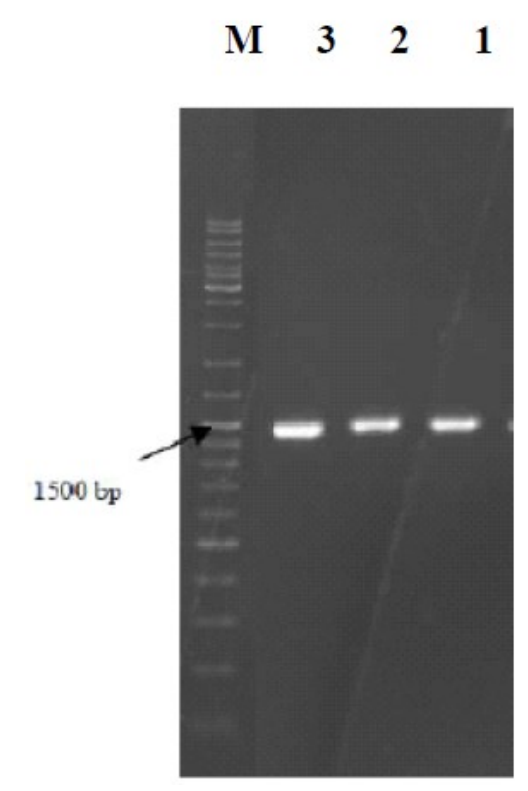

Figure 2. Amplification of 16SrDNA. Lane 1, 2 and 3 are amplicon from soil, salt and sediment respectively. Lane $\mathrm{M}$ is marker.

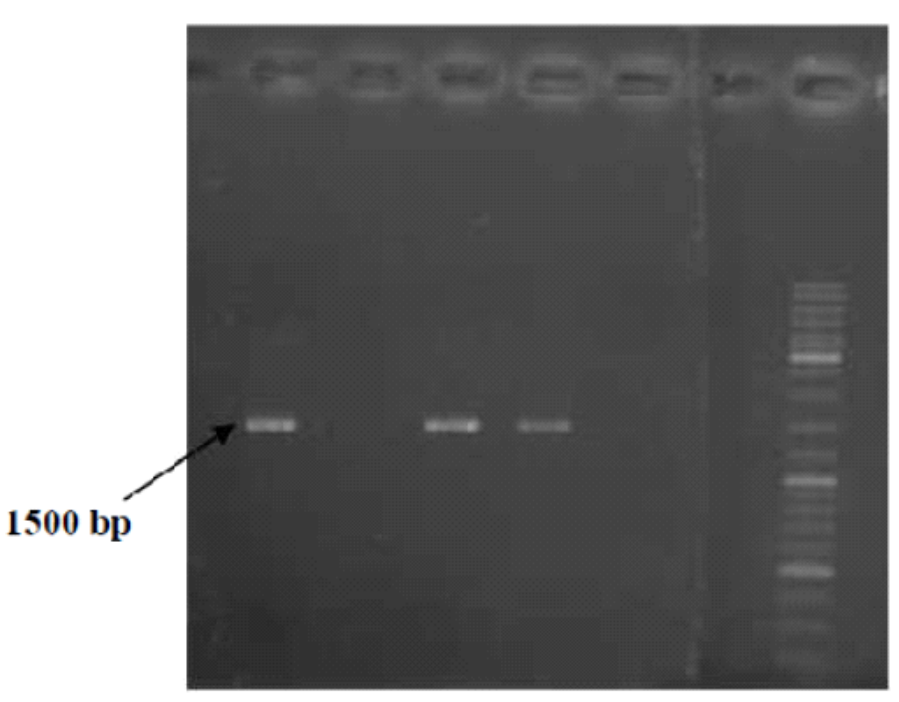

Figure 4. Clones were amplified randomly.

We also showed that the method was effective for the analysis was indigenous microbial communities by PCR-DGGE. We succeeded in demonstrating that community analyses by PCRDGGE were used to detect and isolate bacteria (Figure 5). 


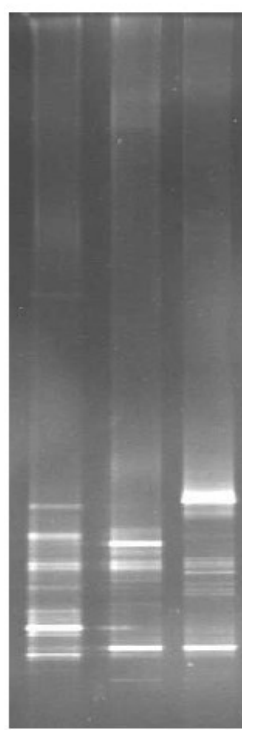

Figure 5. DGGE profiles of DNA extracted from soil, sediment and salt (Lane 1,2 and 3).

\section{Discussion}

Samples were collected from extreme salt habitat. Chemical analysis of saline samples from Urmia Lake showed that $\mathrm{Na}^{+}$and $\mathrm{Cl}^{-}$are the dominant ions; indicate that this lake is a thalassohaline environment. Direct extraction of DNA from samples is necessary for the study of microbial ecology. This method facilitates the analysis of whole microbial communities, including unculturable microorganisms. DNA extraction has been difficult from some type of soils and sediments. Many protocols have been developed to yield DNA for molecular analysis.

In this work, a kit was used to extract DNA. Also, the combination of the kit and skim milk were not effective in DNA extraction.

As a result, no DNA could be extracted from saline samples in either the presence or absence skim milk for an unknown reason, maybe these samples type are outside the scope of the kit, because different commercial soil DNA isolation kits (e.g., UltraClean, Powersoil, and Soil Master) may have a bias towards certain kinds of soil types (e.g., clay, silt, sand, and gravel) [20].

In this study, we used the combination of physical, chemical and mechanical lysis methods for DNA extraction from saline samples.

Saline samples collected from Urmia salt lake have high levels of salinity and other contaminants. These factors include clay colloid, high salt concentration affect DNA extraction efficiency. The factors contribute to the high phosphate retention and high organic carbon content, which are consider to correlate with the difficulty in DNA extraction.

Therefore, samples were washed and removed salt in present tween under agitation. Tween reagent exhibited minimal inhibition and high extraction efficiency. Tween is effective in solubilization [21]. The result suggested that contamination and soluble impurities removed by washing with buffer.

The large amounts of samples were tested for obtaining DNA and good quality DNA could be extracted. In our protocol used high concentration lysozyme enzyme relative to the levels in other published methods, this factor may also be important for extracting DNA. In most reported protocols, the purification methods consist of a series of steps, which can be both time-consuming and costly. In this study, we have developed a simple and cost effective purification method that can be successfully used to obtain high quality DNA. DNA extraction especially from saline samples is known to be very difficult. Here, we added skim milk as a carrier to minimize the degradation and adsorption of nucleic acids to buffer DNA extraction described by Yuko and Naoyuki [5]. The results demonstrated that Skim milk was most effective in allowing extraction of DNA from salt samples. 
Considering these findings, DNA adsorption by clay colloids is considered to be the main reason for the difficulty in DNA extraction. Our method is effective for saline soil, sediment and salt from which it is difficult to extract DNA because of extensive adsorption by samples colloids. Soil harbors a variety of substances that inhibit molecular techniques such as PCR, restriction enzyme digestion, and hybridization. It is difficult to remove all humic substances from soil DNA extracts [12].

Soil and sediment properties such as high clay and organic matter content may contribute to high adsorption of DNA.

The skim milk method is effective for samples which are difficult to extract DNA because of their high adsorption to samples particles. The use of skim milk is more suitable for PCR and costeffective. Addition of skim milk did not affect amplify of DNA extracted.

However, the mechanism by which skim milk enhances the extraction of DNA from samples is not clear and it is not known which constituents of skim milk are responsible for the observed effects. DNA adsorption on soil particles can be affected by organic solutes; such as, proteins coating DNA enhanced the amount of DNA adsorbed by clay [22].

DNA extracted from saline samples was free from inhibitors and, therefore, could be used for efficient PCR amplification.

In addition, PCR amplification using DNA extracted were successful. Thus, this protocol for the isolation of metagenome from the saline samples is useful to study the community.

On the other hand, PCR-DGGE and cloning analysis targeting the 16S rDNA gene and functional gene revealed that salt concentration and inhibitors did not affect general bacterial community structure. Our results demonstrate that this method can be applied in field investigation of diversity.

\section{Conclusion}

In conclusion, we have developed a rapid method to extract high quality DNA with good reproducibility and high yield, which has some obvious advantages over widely used method.

In this protocol, DNA was extracted from saline soil, sediment and salt by combining physical, chemical and mechanical lysis methods. The combine of our method and skim milk was most effective in extracting DNA from saline soil. Therefore, this method may play an important role in the studies of microbial diversity, metagenomic analysis by PCR-DGGE and cloning analysis.

\section{References}

[1] P. Robe et al., Extraction of DNA from soil, European J. Soil Bio. 39 (2003) 183-190.

[2] G.M. Luna, A. Dell'Anno, R. Danovaro, DNA extraction procedure: a critical issue for bacterial diversity assessment in marine sediments, Environ. Microbiol. 8(2) (2006) 308-320.

[3] T. Hattori, Soil aggregates as microhabitats of microorganisms, Biol. Fertil. Soils. 6 (1988) 189203.

[4] L. Ranjard et al., A single procedure to recover DNAfrom the surface or inside aggregates and in various size fractions of soil suitable for PCR-based assays of bacterial communities, Eur. J. Soil Biol. 34 (1998) 89-97.

[5] T.H. Yuko, M. Naouki, An improved DNA extraction method using skim milk from soils that strongly adsorb DNA, Microbes Environment. 19(1) (2004) 13-19.

[6] T.H. Yuko, M. Naouki, Skim Milk Drastically Improves the Efficacy of DNA Extraction from Andisol, a Volcanic Ash Soil, Japan Agricultural Research Quarterly. 39(4) (2005) 247-252. 
[7] K.Y. Kweku, R.S. Todd, Strategy for Extracting DNA from Clay Soil and Detecting a Specific Target Sequence via Selective Enrichment and Real-Time(Quantitative) PCR Amplification, Appl. Environment. Microbiol. (2009) 6017-6021.

[8] J. Li et al., A rapid DNA extraction method for PCR amplification from wetland soils, Lett. Appl. Microbiol. 52 (2011) 626-633.

[9] T. Miao et al., A method suitable for DNA extraction from humus-rich soil, Biotechnol. Lett. 36(11) (2014) 2223-2228.

[10] A. Panigrahy et al., Development of a metagenomic DNA extraction procedure and PCR detection of human enteric bacteria in vegetable salad tissues, Res. Biotechnol. 2(1) (2011) 11-19.

[11] J.S. Rajesh, K. Sivasubramani, S. Jayalakhsmi, Simple, Rapid Method For Direct Isolation Of Metagenomic Dna From Pichavaram Mangrove Sediment, Int. J. Res. Biotechnol. Biochem. 3(1) (2013) 19-21.

[12] M.A. Schneegurt, S.Y. Dore, C.F.J. Kulpa, Direct Extraction of DNA from Soils for Studies in Microbial Ecology, Curr. Issues. Mol. Biol. 5 (2003) 1-8.

[13] J.D. Rhoades, Soluble Salts, In: A.L. Page et al. (ed.), Methods of soil analysis, Part 2, Chemical and microbiological properties - Agronomy. 9 (1982) 167-179.

[14] H.W. Doughty, Mohr's method for the determination of silver and halogens in other than neutral solutions, J. Am. Chem. Soc. 46(12) (1924) 2707-2709.

[15] R.T. Sheen, H.L. Kahler, Effects of Ions on mohr method for chloride determination, Ind. Eng. Chem. Anal. Ed. 10 (1983) 628-629.

[16] S. Turner, K.M. Pryer, V.P.W. Miao, J.D. Palmer, Investigating deep phylogenetic relationships among cyanobacteria and plastids by small subunit rRNA sequence analysis, J. Eukaryot. Microbiol. 46 (1999) 327-338.

[17] D.J. Lane et al., Rapid determination of $16 \mathrm{~S}$ ribosomal RNA sequences for phylogenetic analyses, Proc. Natl. Acad. Sci. 82 (1985) 6955-6959.

[18] G. Muyzer, E.C. Waal, A. Uitterlinden, Profiling of complex microbial populations by denaturing gradient gel electrophoresis analysis of polymerase chain reaction amplified genes encoding for 16Sr DNA, Applied Environment Microbiology, 59 (1993) 695-700.

[19] R.T. Papke et al., Diversity of bacteriorhodopsins in different hypersaline waters from a single Spanish saltern, Environ. Microbiol. 5 (2003) 1039-1045.

[20] M. Tianjin et al., A method suitable for DNA extraction from humus-rich soil, Biotechnol. Lett. 36 (2014) 2223-2228.

[21] M.P. Vinardell, M.R. Infante, The relationship between the chain length of non-ionic surfactants and their hemolytic action on human erythrocytes, Comparative Biochemistry and Physiology Part C: Pharmacology, Toxicology and Endocrinology. 124(2) (1999) 117-120.

[22] K. Saeki, M. Sakai, T. Kunito, Effect of $\alpha$-casein on DNA adsorption by Andosols and by soil components, Biol. Fertil. Soils. 48 (2012) 469-474. 